KONRAD NIKLEWICZ

Marketing Department, The City of Warsaw

ORCID: 0000-0002-1013-8770

konrad.niklewicz@hotmail.com

\title{
Countering frames: how Warsaw and Budapest mayors communicated their international activity
}

Przeciwstawne ramy: jak prezydenci Warszawy

i Budapesztu komunikowali swoją aktywność międzynarodową

Słowa kluczowe:

ramowanie, Trzaskowski,

Karácsony, Twitter,

Facebook
Keywords:

framing, Trzaskowski, Karácsony, Twitter, Facebook 


\section{Przeciwstawne ramy: jak prezydenci Warszawy i Budapesztu komunikowali swoją aktywność międzynarodową}

Autor artykułu skupia się na analizie wypowiedzi prezydenta Budapesztu Gergely Karácsonyego i prezydenta Warszawy Rafała Trzaskowskiego w mediach społecznościowych, dotyczących ich aktywności międzynarodowej, zauważając, że komunikacja prowadzona jest $\mathrm{w}$ kontekście nieobiektywnego przekazu na ich temat $\mathrm{w}$ mediach rządowych. Przeprowadzone $\mathrm{w}$ artykule badania weryfikują wykorzystanie ram komunikacyjnych, które skłaniają do określonej, pożądanej interpretacji i uzasadnienia zaangażowania burmistrzów w relacje międzynarodowe. Analizując sposób komunikowania międzynarodowej aktywności samorządów, autor dostarcza dodatkowych informacji, pozwalających lepiej zrozumieć podejmowane działania w tym obszarze. Artykuł jest głłosem w dyskusji o roli miast w przyciąganiu uwagi międzynarodowej opinii publicznej w kwestii problemów z praworządnością i jakością demokracji w Polsce i na Węgrzech.

\section{Countering frames: how Warsaw and Budapest mayors communicated their international activity}

This paper examines the Mayor of Budapest, Gergely Karácsony and Mayor of Warsaw Rafał Trzaskowski social media communication related to their international activity in the context of government-linked media bias. The paper's research verifies the use of communication frames that prompt a given, desired interpretation and justification of mayors' transborder engagement.

By exploring its communication aspect, the paper adds to a better understanding of local governments' international activity. It also adds to the debate on the role of cities in drawing international public attention towards problems with the rule of law and the quality of democracy in Poland and Hungary. 


\section{Introduction}

n October 2018, Rafał Trzaskowski (centrist Civic Platform party) won the race for the Mayor of Warsaw, beating Patryk Jaki (backed by the ruling Law and Justice party) ${ }^{1}$. In October 2019, Gergely Karácsony (supported by a wide range of opposition parties) successfully challenged the incumbent Mayor of Budapest, Istvan Tarlos (member of the ruling party Fidesz) ${ }^{2}$. Following the success, Trzaskowski and Karácsony have become the leading figures of the opposition parties. In 2020 Trzaskowski was chosen to be the Civic Party candidate in national presidential elections (a race he narrowly lost to incumbent Andrzej Duda) ${ }^{3}$. As for Karácsony, by the time of writing this paper, he was considered a leading candidate of the coalition of opposition parties in parliamentary elections set for $2022^{4}$.

Trzaskowski and Karácsony share not only similar political positions but some personal features too. They are the same generation (in 2021, 49 and 46 years old, respectively). They also have comparable intellectual backgrounds: both are political scientists, both are known for their interest in progressive political issues (gender, LGBT rights, social equality, sustainable economy etc.).

From the beginning of their terms, the mayors of Warsaw and Budapest engaged in international activity. In late 2019, they initiated an unprecedented political project - the Pact of the Free Cities. Signed on 16 December 2019 in Budapest (where Trzaskowski and Karácsony

1 Oficjalne wyniki wyborów 2018 Warszawa. Trzaskowski zdobył 56,67 proc. Dla kogo Rada Miasta?, gazeta.pl, 24 X 2018 [accessed: 3 IV 2021], available online <https:// wiadomosci.gazeta.pl/wiadomosci/7,114884,24080096,oficjalne-wyniki-wyborow2018-warszawa-trzaskowski-zdobyl.html>.

2 Agence France Presse, Blow for Hungary PM Orbán as opposition wins Budapest mayoral race, "The Guardian" [online], 14 X 2019 [accessed: 28 III 2021], available online: <https://www.theguardian.com/world/2019/oct/13/opposition-parties-candidatewins-budapest-mayoral-race $>$.

3 Presidential election the Republic of Poland 2020, National Electoral Commission, 3 IX 2020 [accessed: 21 III 2021], available online: <https://prezydent20200628.pkw. gov.pl/prezydent20200628/en>.

4 E. Inotai, Governing, not winning, seen greater test for Hungary's united opposition, balkaninsight.com, 24 III 2021 [accessed: 3 IV 2021], available online: <https://balkaninsight.com/2021/o3/24/governing-not-winning-seen-greater-testfor-hungarys-united-opposition/ $>$. 
were joined by the mayor of Bratislava Matus Vallo and mayor of Prague Zdeněk Hřib), the "Pact" was described as an open platform of cooperation, focusing on access to EU funding, climate change, but also on promotion of shared values: freedom, human dignity, democracy, equality, and the rule of $\mathrm{law}^{5}$. Mayors also pledged to launch projects in policy areas such as sustainable city planning, social inclusion and housing ${ }^{6}$. The signature of the Pact was followed by numerous joint actions, like the letter to German Chancellor Angela Merkel, calling for establishing directly accessible urban funds within the EU's budget?

Mayors' Trzaskowski and Karácsony international activity can be interpreted as part of a broader process of cities fledgling political emancipation. Cities account for at least $70 \%$ of the world's $\mathrm{GDP}^{8}$, and they play a leading role in culture and education; they are "machines for creating citizens" . By 2030 two-thirds of the world population might live in cities ${ }^{10}$. Yet, their political clout contrasts their social and economic weight. In this context, researchers discuss the cities' strive for a greater political role. J. Zielonka believed that future Europe's governance structure might look like a junction box with numerous points of interaction and intersection, with cities in the lead ${ }^{11}$.

5 Pakt Wolnych Miast podpisany, Warszawa. Oficjalny portal miasta, 17 XII 2019 [accessed: 3 IV 2021], available online: 〈https://www.um.warszawa.pl/aktualnosci/ pakt-wolnych-miast-podpisany $>$.

6 Pact of Free Cities, The official website of the Municipality of Budapest, 16 XII 2019 [accessed: 3 IV 2021], available online: <https://budapest.hu/sites/english/ Lapok/2020/pact-of-free-cities.aspx>.

7 V4C mayors' letter to Chancellor Merkel on direct, green, urban funding in the EU's next Multiannual Financial Framework, The official website of the Municipality of Budapest, 16 VII 2020 [accessed: 3 IV 2021], available online: <https://budapest.hu/sites/english/Lapok/2020/v4c-mayors-letter-to-chancellor-merkel-on-directgreen-urban-funding-in-the-eus-next-multiannual-financial-framework.aspx $>$.

8 K. Niklewicz, Retaking the cities. A Plan for the centre-right, Wilfred Martens Centre for European Studies, Brussels 2020, p. 3, available online [accessed: 7 III 2021]: <https://www.martenscentre.eu/wp-content/uploads/2020/11/CES_POLICY-BRIEF_ Retaking-cities-V3.pdf $>$.

9 After disaster, "The Economist", 13 VI 2020, p. 9.

10 F. Gaub et al., Global trends to 2030 challenges and choices for Europe, European Strategy and Policy Analysis System, Brussels 2019, available online [accessed: 8 III 2021]: 〈https://ec.europa.eu/assets/epsc/pages/espas/index.html〉.

11 J.Zielonka, Is the EU doomed?, Polity Press, Cambridge 2014, p. 107. 
In his view, large cities were best placed to fill the political and administrative vacuum resulting from the loss of power at the national level. London, Paris, Milan and Frankfurt are not only the engines of the European economy, but they also progressively assume political, social and cultural functions traditionally carried by states, he wrote. ${ }^{12}$ For B. Barber, sovereign states were too large to engage civic participation and too small to address global power; as polis was the bedrock of modern democracy, now bigger polis (cities) might be again the way forward ${ }^{13}$. At the same time, the devolution of power to local levels does not necessarily dilute the importance of federal and state governments ${ }^{14}$. The two can go in parallel. Mayors Trzaskowski and Karácsony transborder activity fit Zielonka's and Barber's concept - through their actions, they complemented governments' activity.

The interaction between the governments' foreign policy and the transborder activity of local governments merits further theoretical delimitation. However, one thing is certain: the international activity of local governments provides plenty of communication opportunities.

Drawing from the framing theory toolkit, I examine the following hypothesis: in their communication on Facebook and Twitter related to their international engagement, Trzaskowski and Karácsony applied communication frames to prompt interpretation and justification for their international engagement and to put forward the own-created image of mayors as political agents.

Mayors' social media communication is the main subject of my research. I ask the following research questions: what was the media environment they operated in? Did mayors use communication frames? And if so, what was their construction? What words, groups of words, expressions were used to construct the frame? What was their meaning? Did the framing offer a given interpretation and justification of mayors' transborder engagement?

By finding the frames and deconstructing them, I examine strategies in mayors' communication related to their international activity. I investigate

J. Zielonka, Is the EU..., p. 90.

13 B. Barber, Gdyby burmistrzowie rządzili światem, transl. H. Jankowska, K. Makaruk, Muza, Warszawa 2014, p. 18, [English version: If mayors ruled the world. Dysfunctional nations, Rising Cities 2013].

14 B. Katz, J. Nowak, The new localism. How cities can thrive in the age of populism, Brookings Institution Press, Washington 2018, p. 10. 
how mayors tried to influence public opinion forming, in the context of biased media coverage, used against them by the government-controlled media. Since the said coverage is a crucial as perspective (reference) for mayors' communication, I examine a wide selection of examples.

\section{Literature review and theoretical context of the study}

The theoretical basis for the study is the framing theory, dating back to the 1970 s and $1980 \mathrm{~s}^{15}$. The theory sits on the confluence of political science, media science and sociology. It is part of constructivism current, as it fits one of its claims: social reality can be constructed through communication. As S. D. Reese wrote, communication frames are organising principles that work to structure the world meaningfully ${ }^{16}$. According to R. M. Entman, framing means selecting and making some parts of reality more salient in communication in such a way as to promote particular problem definition, interpretation or evaluation ${ }^{17}$. Frames tell the receivers how they should interpret a fact or an event.

In general, a frame is a cognitive structure residing in different places on different levels. It can be embedded in the recipient's mind, unconsciously used in daily life, or consciously used by the message creator, aiming to strike a particular chord among recipients ${ }^{18}$. Framing in communication induces to use of specific mental structures to judge a given message. Alternative framing of a given issue in communication can yield different interpretations of the same event or fact, as words activate different mental frames.

Framing consists of four steps: input, frame building, the frame's appearance, and frame setting (the latter include individual-level effects

15 E. Goffman, Frame analysis. An essay on the organization of experience, Northeast University Press, Boston 1986, p. 21.

16 S. D. Reese, Prologue - framing public life: a bridging model for media research, [in:] eds S. D. Reese, O. H. Gandy, A. E. Grant, Framing public life: perspectives on media and on our understanding of the social world, Routledge, London 2001, p. 11.

17 R. M. Entman, Framing: towards clarification of a fractured paradigm, "Journal of Communication" 1993, vol. 43(4), p. 52.

18 J. Maćkiewicz, Ramy interpretacyjne jako narzędzie badań medioznawczych, „Studia Medioznawcze" 2020, vol. 21, no. 3 (82), p. 617, 619. 
of framing: opinions, attitudes, attribution of responsibility etc. $)^{19}$. Since framing influences interpretation, it helps to achieve desired, persuasive results of communication ${ }^{20}$.

\section{Materials and Methods}

My paper examines content published online (late 2019 - beginning 2021). Two social platforms were selected for the study: Facebook and Twitter. The former was chosen because of its popularity among the population - Facebook is the largest social media platform globally ${ }^{21}$. In March 2021, an estimated 21,5 million Poles declared using the domain facebook.com ${ }^{22}$. In Hungary, Facebook is the dominant social media brand too ${ }^{23}$. Twitter usage is less intensive (6th ranked global social media platform ${ }^{24}$ ); however, it is a platform of choice for political professionals (politicians, journalists, activists, pundits and commentators) and citizens whose interest in politics is clearly above the average. As Z. Fazekas et al. noted, Twitter allows candidates to highlight issues repeatedly, instantly, at a timing of their own choice ${ }^{25}$. Additionally, it can also create an "information cascades" effect, leading to a viral effect ${ }^{26}$.

19 D. A. Scheufele, Framing as a theory of media effects, "Journal of Communication", March 1999, vol. 49, issue 1, p. 115.

20 J. Maćkiewicz, Ramy interpretacyjne jako narzędzie badan medioznawczych, „Studia Medioznawcze" 2020, vol. 21, no. 3 (82), p. 620.

21 C. Newberry, 47 Facebook stats that matter to marketers in 2021, blog.hootsuite.com, 11 I 2021 [accessed: 28 III 2021], available online: 〈https://blog.hootsuite.com/ facebook-statistics/>.

22 PBI, Wyniki badania Mediapanel za marzec 2021, Polskie Badanie Internetu Gemius, 6 IV 2021 [accessed: 6 IV 2021], available online: <https://pbi.org.pl/ badanie-mediapanel/wyniki-badania-mediapanel-za-marzec-2021/>.

23 M. Dunai, Hungary says to target tech giants over alleged manipulation of social media platforms, Reuters [online], 26 I 2021 [accessed: 18 IV 2021], available online: $<$ https:// www.reuters.com/article/hungary-social-media-restrictions-idUSL8N2K13PY $\rangle$.

24 C. Newberry, 36 Twitter stats all marketers need to know in 2021, blog.hootsuite.com, 3 II 2021 [accessed: 28 III 2021], available online: <https://blog.hootsuite.com/ twitter-statistics/>.

25 Z. Fazekas et al., Elite-public interaction on twitter: EU issue expansion in the campaign, "European Journal of Political Research" 2021, vol. 6o, issue 2, p. 378-379.

26 Z. Fazekas et al., Elite-public interaction on twitter: EU issue expansion in the campaign, "European Journal of Political Research" 2021, vol. 6o, issue 2, p. 378-379. 
Because of their popularity, both in the general public and opinion-forming elite), social platforms are an integral part of the media environment ${ }^{27}$.

All content studied in this paper was manually retrieved. In total, 27 Trzaskowski and Karácsony posts related to international activity were examined. The choice of posts (and their number) was intentional: I selected only the posts pertaining to political events, processes or issues in which both mayors participated. Such selection allowed to compare how the same events (independent variables) were communicated and interpreted by mayors (the content of the posts being the dependent variable). While investigating the potential frames applied by mayors, I used the induction methodology, as described by $\mathrm{J}_{\text {. Maćkiewicz }}^{28}$ : I focused on the thematic and rhetorical structure of the frame. I extracted words (phrases) constituting the frame, assessed their meaning and checked for eventual repeatability. I also examined the visual content of the publications to verify how it corroborated with the verbal layer. While concentrating on frame building, one of the four crucial elements of the framing process (as defined by D. A. Scheufele), I fell in line with one of the most common approaches within the framing studies ${ }^{29}$.

I had the Hungarian-language content professionally translated. Also, I contacted mayors' communication teams to obtain social media metrics ${ }^{30}$.

\section{State-controlled and state-linked media coverage of mayors}

Trzaskowski's and Karácsony's political situation bore many similarities, and so did the media environment in Poland and Hungary in 2019-2021. In both countries, government-controlled (or government-linked) media, especially television channels, partially resembled what M. Schudson called

27 K. Niklewicz, Communicating reform through social media: opportunities and risks, "e-Politikon" 2017, no. XXI, p. 31.

28 J. Maćkiewicz, Ramy interpretacyjne jako narzędzie badań medioznawczych, „Studia Medioznawcze" 2020, vol. 21, no. 3 (82), p. 622.

29 K. Franczak, Analiza ramowania, [in:] Analiza dyskursu publicznego. Przegląd metod i perspektyw badawczych, eds M. Czyżewski, M. Otrocki, T. Piekot, J. Stachowiak, Wydawnictwo Akademickie Sedno, Warszawa 2017, p. 155.

30 Only the administrators of profiles can access the metrics like the reach. 
self-conscious organs of propaganda ${ }^{31}$. As one researcher noted, "in certain areas, we are past even the Russian $\mathrm{tv}^{\prime \prime 32}$. The situation seems particularly aggravated in Hungary, where most media are either owned by the state (i.e. government-controlled) or government-linked ${ }^{33} 34$.

Mayor Trzaskowski's unfair coverage in government-controlled media reached its peak in 2020 when he ran in the Polish presidential election. In that period, $87 \%$ of all news related to Trzaskowski, aired in "Wiadomości" (the news programme of the TVP1 channel), was negative ${ }^{36}$. Not a single time "Wiadomości" mentioned him in a positive manner. Following are the selected titles: The festival of Trzaskowski's failures (aired 6 VI 2020), Trzaskowski gave up honesty (6 VI 2020), Trzaskowski supports the LGBT and anti-clericalism (10 VI 2020), Trzaskowski's empty promises (11 VI 2020) ${ }^{37}$, We are fed up with Trzaskowskis's hypocrisy (16 VI 2020) ${ }^{38}$.

Unobjective coverage of Trzaskowski continued after the elections. In August 2020, when the sewage pipe broke (for a second time in a row, probably due to the errors in its construction, completed years before Trzaskowski took office), government-controlled media were quick to blame the accident on mayor Trzaskowski negligence: Ecological disaster

31 M. Schudson, The news media as political institutions, "Annual Review of Political Science" 2002, vol. 5, p. 249.

32 A. Olender, "Prześcignęliśmy nawet rosyjska telewizję". Badacz mechanizmów propagandy ocenia "Wiadomości” TVP, natemat.pl, 9 VII 2020 [accessed: 21 III 2021], available online: <https://natemat.pl/314153,wiadomosci-tvp-w-czasie-kampanii-wyborczej-medioznawca-o-propagandzie\# $>$.

33 E. Zgut, Orbán wants to further restrict the independent media. Hungary is a warning to Poland, Rule of Law, 23 II 2021 [accessed: 28 III 2021], available online: <https:// ruleoflaw.pl/orban-wants-to-restrict-independent-media-hungary-poland/ $>$.

34 A. Sikorski, Is the end near for Viktor Orbán?, Human Rights Foundation - hrf.org, 25 III 2021 [accessed: 27 III 2021], available online: <https://hrf.org/press_posts/ is-the-end-near-for-viktor-orban/>.

35 S. Ozsvath, Hungary's Fidesz party seeks to conquer social media, DW [online], 6 II 2021 [accessed: 6 IV 2021], available online: <https://www.dw.com/en/hungarysfidesz-party-seeks-to-conquer-social-media/a-56479198 $\rangle$.

36 J.Stawiany, „Wiadomości” o Trzaskowskim źle albo wcale, press.pl, 19 VI 2020 [accessed: 21 III 2021], available online: <https://www.press.pl/tresc/62151, wiadomosci_tvp-o-rafale-trzaskowskim-tylko-negatywnie $>$.

37 J. Stawiany, „Wiadomości” o Trzaskowskim...

38 Mamy dość hipokryzji Trzaskowskiego, wiadomosci.tvp.pl [online], 16 VI 2020. 
in Warsaw ${ }^{39}$, Mayor Trzaskowski helpless in the face of the breakdown ${ }^{40}$, Warszawa poisons the Vistula river and the Baltic Sea again ${ }^{41}$, The biggest environmental disaster in the world ${ }^{42}$. On one occasion, the news channel TVP Info manipulated a picture to suggest that the 2020 breakdown severely affected the Vistula river ${ }^{43}$.

Trzaskowski international activity was the subject of propaganda attacks too. Mayors' open letter to the European Commission, sent shortly before the crucial EU Summit in December 2020, was commented in the news channel TVP Info as a "stab in the back".44

Mayor of Budapest Gergely Karácsony received similar coverage. In government-controlled or -linked media, any news about the opposition was framed in the negative light, E. Zgut said ${ }^{45}$. Karácsony was blamed for many alleged failures: from the rise of coronavirus cases in elderly rest-houses to the lack of air-conditioning in the capital's metro ${ }^{46}$. On 21 I 2021, Híradó, the leading news program of the state-controlled MTVA, alarmed the public about the property sellout allegedly planned by "local government led by Gergely Karácsony", "bypassing the Fidesz leadership, without even asking the locals"47. On 2 III 2021, the HirTV channel alleged that Mayor Karácsony administration "intercepted" funds designed to aid entrepreneurs. To strengthen the negative frame, it quoted a representative of the Hungarian Catering Industry Association, who spoke of a "brazenly

39 Katastrofa ekologiczna w Warszawie, wiadomości.tvp.pl [online], 28 VIII 2020.

40 Prezydent Trzaskowski bezradny wobec awarii, wiadomości.tvp.pl [online], 1 IX 2020.

41 Warszawa znów zatruwa Wisłę i Bałtyk, wiadomości.tvp.pl [online], 23 XII 2020.

42 Wody Polskie o „Czajce”: największa katastrofa ekologiczna na świecie, rdc.pl, 16 IX 2020.

43 P. Czernich, Awaria Czajki. TVP ilustruje zanieczyszczenia zdjęciem z 2015 r., onet.pl, 4 IX 2020.

44 A. Gąbka, List Trzaskowskiego do Brukseli. „Wbicie sztyletu w plecy polskiemu rządowi”, tvp.info [online], 7 XII 2020.

45 E. Zgut, Orbán wants to further restrict the independent...

46 E. Inotai, Budapest Mayor: I'm not challenging Orban yet, Balkan Insight, 11 VII 2020 [accessed: 5 IV 2021], available online: <https://balkaninsight.com/2020/o7/11/ budapest-mayor-im-not-challenging-orban-yet/ $>$.

47 MTI, Megkkezdte a fóváros kiárusitását Karácsony Gergely, Hirado.hu, 21 I 2021 [accessed: 6 IV 2021], available online: <https://hirado.hu/belfold/belpolitika/cikk/2021/o1/21/ megkezdte-a-fovaros-kiarusitasat-karacsony-gergely\# $>$. 
arrogant move" on the part of "the left-wing leadership" (referring to the political affiliation of Karácsony) ${ }^{48}$. Interview with Hungarian Prime Minister Viktor Orban, aired by the state news channel M1 on 11 IX 2020, is another example of Karácsony's demeaning: his initiatives to fight against covid19 pandemics were compared to disputable attempts to reorganise street infrastructure ${ }^{49} 50$. Like in the case of Trzaskowski, Karacsony international activity was criticised in government-linked media. For example, on 12 June 2020, Magyar Nemzet condemned Karácsony for making numerous ideological or national proposals, including proposals to the European Union on crisis management, while disregarding pressing local issues like the renovation of Budapest's famous Széchenyi Chain Bridge ${ }^{51}$.

\section{Research results: mayors' social media communication}

Mayor Karácsony introduced the topic of international activity in his social media feed soon after taking office. On 29 X 2019, while announcing the creation of a union of four capitals (Prague, Bratislava, Budapest and Warsaw), Karácsony announced: "the EU's funds for development would go directly to those cities ${ }^{\prime \prime 2}$, framing the Pact as a way to guarantee EU funding for cities. On 16 XII 2019, Karácsony introduced a frame of direct civic representation to justify his international actions (“This is

48 Magyar Nemzet: Karácsonyék lenyúlják a vendéglátósoknak megítélt bértámogatást, HirTV [online], 2 III 2021 [accessed: 6 IV 2021], available online: <https://hirtv.hu/ ahirtvhirei/magyar-nemzet-karacsonyek-lenyuljak-a-vendeglatosoknak-megiteltbertamogatast-2517790>.

49 A. Vass, Coronavirus: Budapest mayor denies PM Orbán's claims about capital's 100 billion plus, Hungary Today [online], 14 IX 2020 [accessed: 5 IV 2021], available online: <https://hungarytoday.hu/coronavirus-budapest-mayor-karacsony10o-billion-government/ $>$.

50 MTI-Hungary Today, Coronavirus - Orbán: Virus must not be allowed to paralyse Hungary again, Hungary Today [online], 11 IX 2020 [accessed: 5 IV 2021], available online: $<$ https://hungarytoday.hu/coronavirus-orban-virus-paralyse-hungaryborder-measures/ $>$.

51 Lánchíd-ügy: Karácsony a saját közguyulési határozatuknak sem tett eleget, Magyar Nemzet [online], 12 VI 2020 [accessed: 6 VII 2021], available online: <https:/magyarnemzet.hu/ belfold/lanchid-ugy-karacsony-a-sajat-hatarozatuknak-sem-tett-eleget-8236251/>.

52 G. Karácsony, FB, 29 X 2019 (full links and access date to Facebook (FB) / and Twitter (T) posts are listed in in Bibliography section, Social media content subsection). 
what several hundred thousand of our voters expect us to do"). ${ }^{53}$ He also wrote of unity and alliance ("Budapest, Bratislava, Prague and Warsaw speak with one voice" ${ }^{54}$,"We have a great deal in common" ${ }^{25}$ ). Also, a third frame was introduced: cities as an alternative image of the countries, contrasting with the image created by central governments ("Hungary, Czechia, Slovakia and Poland are not to be identified with their respective central governments' policies") ${ }^{56}$. Publications' visual layer corresponded with verbal: pictures of mayors walking together in the streets of Budapest, symbolic handshake gestures (one-for-all style) were used.

On 12 II 2020, the mayor of Budapest reused the frame of cities' direct access to EU funds ${ }^{57}$. In June 2020, while informing about a letter to the head of the European Council, he re-emphasised the togetherness and people's direct representation: "In the name of 5 million citizens, together with my counterparts from Bratislava, Prague and Warsaw" ${ }^{\prime 58}$. A month later, he framed the crux of EU-level negotiations (the debate on introducing the rule-of-law criteria) as "anti-corruption regulations" ${ }^{\text {"29 }}$. On 15 VII 2020, Karácsony contrasted the local governments' unity with the government's isolation ${ }^{60}$. On 7 IX 2020 mayor of Budapest re-framed the local governments' activity as an alternative image of the country (and whole region): "There is so much more to our region than right-wing populism" ${ }^{\prime 61}$. The frame referring to an alliance was repeated in December 2020, as "joint demand of 249 Hungarian and Polish local governments" ${ }^{\prime 62}$. The day after, Karácsony reiterated: "if our govts defy \#ruleoflaw, we $249 \mathrm{HU} \&$ PL municipalities urge EU institutions to divert \#nextgenerationeu funds to the local level". ${ }^{63}$ Again,

53 G. Karácsony, FB, 16 XII 2019.

54 G. Karácsony, FB, 16 XII 2019.

55 G. Karácsony, FB, 16 XII 2019.

56 G. Karácsony, FB, 16 XII 2019.

57 G. Karácsony, FB, 12 II 2020.

58 G. Karácsony, FB, 17 VI 2020.

59 G. Karácsony, FB, 15 VII 2020.

60 G. Karácsony, FB, 15 VII 2020.

61 G. Karácsony, T, 7 IX 2020.

62 G. Karácsony, FB, 7 XII 2020.

63 G. Karácsony, FB, 8 XII 2020. 
the central government approach ("selfishness and anti-European stance") was contrasted with local governments' stance ("we can make sure the help reaches those in need") ${ }^{64}$. The mayor of Budapest kept consistently framing EU rules (rule-of-law criteria) as "the anti-corruption measures" ${ }^{\prime 65}$. The frame implying that rule-of-law mechanisms are the safeguards against funds' abuse reappeared on 11 XII $2020^{66} 67$. A few days earlier, on 9 XII 2020, a unique EU-themed picture (Budapest Statue of Liberty illuminated in EU-blue light) was used to grab viewers' attention.

Mayor Rafał Trzaskowski framed the direct cooperation with other local governments as a tool to address challenges ("climate change, quality of air, social inequalities - in these areas we must act together ${ }^{168}$ ) and to stay in touch with grassroots ("closest to the people and their daily issues" ${ }^{\prime 69}$ ). Like Karácsony, Trzaskowski contrasted the image of local governments with that of the central government. On 10 X 2019, he wrote: "Today I had the privilege to represent Warsaw at $\mathrm{C}_{4}$ o Summit in Copenhagen /.../ At this conference, the Law and Justice government, together with Brasilian president boasting about the Amazon jungle logging and us President denying the global warming, are all considered global pariah! Shame!"70.

On 15 and again on 16 XII 2019, Trzaskowski justified the "Pact" as "a common declaration and obligation to act to strengthen the European community, to face the biggest challenges of our time: the climate change, the expansion of political extremism and populism, and the consequences of the latter: the crisis of liberal democracy ${ }^{71}{ }^{72}$. Accompanying pictures (mayors' signatures shown on the text of Pact) reinforced the message of togetherness. On 16 XII 2019, Trzaskowski tweeted how cooperation will work in practice: "We will share experiences and learn from each other.

64 G. Karácsony, FB, 7 XII 2020.

65 G. Karácsony, FB, 9 XII 2020.

66 G. Karácsony, FB, 11 XII 2020.

67 G. Karácsony, T, 11 XII 2020.

68 R. Trzaskowski, T, 26 VI 2019.

69 R. Trzaskowski, T, 25 VI 2019.

70 R. Trzaskowski, FB, 10 X 2019.

71 R. Trzaskowski, FB, 15 XII 2019.

72 R. Trzaskowski, FB, 16 XII 2019. 
Our experts and officials systematic consultation will be the key aspect of the Pact functioning"73.

In February 2020, Trzaskowski reintroduced the frame of direct EU funding: “Today, in Brussels, we press for the citizens' interests, pleading for additional, direct EU funding for local governments" ${ }^{\prime 74}$. He also added: "Cities play a key role in fighting climate change"75. The idea of local governments' direct access to EU funds reappeared in July $202 \mathrm{O}^{76}$, while the pattern of local governments' collaboration returned on 13 XI 2020 at the occasion of the International Tolerance Day ${ }^{77}$.

On 7 XII 2020, Trzaskowski reused the frame of local governments, creating alternative images of countries ("The voice of Law and Justice is not the voice of all Poles. Viktor Orban voice is not that of all Hungarians" ${ }^{m 79}$ ). The same month Trzaskowski repeatedly used the frame of securing EU funding for citizens ("independently from Jarosław Kaczyński's and Viktor Orban's pity party games") ${ }^{80} 8182$. An eye-catching picture (Mermaid, the symbol of Warsaw, draped in EU flag) was used ${ }^{83}$.

Facebook and Twitter posts, examined in this paper, scored a total reach of over 10 million (Trzaskowski's - 8,7 million, Karácsony - 1,4 million).

\section{Discussion and conclusion}

The research results validate the paper's hypothesis: mayors consistently applied frames to induce their interpretation of local governments' international activity and enhance their image as pro-European political

73 R. Trzaskowski, T, 16 XII 2019.

74 R. Trzaskowski, T, 12 II 2020.

75 R. Trzaskowski, T, 12 II 2020.

76 R. Trzaskowski, FB, 17 VII 2020.

77 R. Trzaskowski, FB, 13 XI 2020.

78 R. Trzaskowski, FB, 16 XI 2020.

79 R. Trzaskowski, FB, 7 XII 2020.

80 R. Trzaskowski, FB, 7 XII 2020.

81 R. Trzaskowski, FB, 8 XII 2020.

82 R. Trzaskowski, FB, 9 XII 2020.

83 R. Trzaskowski, T, 9 XII 2020. 
actors able to form and manage alliances. Through frames used in social media, they actively tried to offer an alternative vision to the one provided by the state-controlled (or state-linked) media.

Three frames dominated. Mayors put forward the interpretation of international activity as a way to exercise the citizens' direct representation, a tool to secure EU funding for cities, irrespectively of national government decisions. Finally, the international activity of Warsaw and Budapest was framed as a way to create an alternative image of countries/ CEE region, contrasting the central governments' isolation and anti-European stance with local communities (cities) ability to strike alliances.

Interestingly, not always the frames applied by mayors mirrored each other. In one instance (EU-level talks on the rule-of-law criteria in December 2020), they differed. While Karácsony focused on framing the rule-of-law procedures as anti-corruption measures, Trzaskowski stuck to the concept of securing the EU funds for cities independently from the actions of governments. However, the latter frame was used by Karácsony, too, a few months earlier. One should also notice that Trzaskowski used the climate-change frame (as justification for local governments activity) more often.

The exact measurement of how Trzaskowski and Karácsony's frames in social media impacted public opinion goes beyond the scope of this paper. However, one should acknowledge that Karácsony and Trzaskowski's frames influenced legacy media coverage, in line with earlier literature findings $\mathrm{s}^{84}$. For example, on 11 II 2020, "Politico" reported that Bratislava, Budapest, Prague and Warsaw presented themselves to the EU "as alternative partners to their national governments" ${ }^{\prime 25}$. On 13 II 2020, the EUobserver news agency noted: "The leaders of Budapest, Bratislava, Prague and Warsaw, who banded together in December, want to reverse the image of central Europe, which is often seen as the Eu's obstructionist club"86.

84 D. A. Scheufele, Framing as a theory of media effects, "Journal of Communication", March 1999, vol. 49, issue 1, p. 116.

85 L. Bayer, S. Mortkowiz, Central Europe mayors pitch for EU cash to fight populism, Politico [online], 11 II 2020 available online: <https://www.politico.eu/article/ central-europe-mayors-pitch-for-eu-cash-to-fight-populism/ $\rangle$.

86 E. Zalan, Central Europe mayors join in direct EU funds plea, "EUobserver" [online], 13 II 2020 [accessed: 11 III 2021], available online: < https://euobserver.com/political/ $147435>$. 
It is fair to assume that the content of mayors' social media communication was meant to draw the international community (in particular EU countries' elites and public opinion) attention to problems with the rule of law and the quality of democracy in Poland in Hungary. Given the echo in legacy Western media, the goal has been achieved - at least partially.

The available literature is not yet conclusive on measuring the effects of social media communication on public opinion forming. Numerous researchers agree such an impact exists. "Facebook has become central to people's experience of the world", C. R. Sunstein wrote ${ }^{87}$. In a landmark study from 2012, R. M. Bond et al. concluded that political mobilisation via Facebook worked ${ }^{88}$. S. Lindgren claimed that social media led to a noticeable augmentation of social processes; their potential translated into more extensive and faster political mobilisation ${ }^{89}$. However, there are dissent opinions: C. Byrne, in his examination of the 2015 UK General elections, concluded that there was no evidence that social media played a decisive role in the election result or turnout in $2015^{90}$.

Further research is needed to measure to what extent mayors' Karácsony and Trzaskowski's social media communication influence public opinion. Nevertheless, this study confirms that they did try to achieve the goal, consistently framing their international activity.

I wish to thank Oliver Pilz, City of Budapest Diplomacy Officer, and Stefan Kabat, The City of Warsaw Communication Officer, for their assistance in data gathering.

87 C. R. Sunstein, \#republic, Princeton University Press, Princeton 2017, p. 2.

88 R. M. Bond, C. J. Fariss, J. J. Jones, A. D. I. Kramer, C. Marlow, J. E. Settle, J. H. Fowler, A 61-million-person experiment in social influence and political mobilization, "Nature" 2012, vol. 489 (7415), p. 295-298.

89 S. Lindgren, Digital media \& society, Sage, London 2017, p. 294.

90 C. Byrne, Getting engaged? The relationship between traditional, new media and the electorate during the 2015 UK general election, Reuters Institute for the Study of Journalism, University of Oxford, Oxford 2015, p. 5. 


\section{Bibliography}

After disaster, "The Economist", 13 VI 2020.

Agence France Presse, Blow for Hungary PM Orbán as opposition wins Budapest mayoral race, "The Guardian" [online], 14 X 2019 [accessed: 28 III 2021], available online: <https://www.theguardian.com/world/2019/oct/13/opposition-partiescandidate-wins-budapest-mayoral-race $>$.

Barber B., Gdyby burmistrzowie rządzili światem, transl. H. Jankowska, K. Makaruk, Muza, Warszawa 2014, [English version: If mayors ruled the world. Dysfunctional nations, Rising Cities 2013].

Bayer L., Mortkowiz S., Central Europe mayors pitch for EU cash to fight populism, Politico [online], 11 II 2020 [accessed: 11 III 2021], available online: <https://www.politico. eu/article/central-europe-mayors-pitch-for-eu-cash-to-fight-populism/ $\rangle$.

Bond R. M., Fariss C. J., Jones J. J., Kramer A. D. I., Marlow C., Settle J. E., Fowler J. H., A 61-million-person experiment in social influence and political mobilisation, "Nature" 2012, vol. 489 (7415).

Byrne C., Getting engaged? The relationship between traditional, new media and the electorate during the 2015 UK general election, Reuters Institute for the Study of Journalism University of Oxford, Oxford 2015.

Czernich P., Awaria Czajki. TVP ilustruje zanieczyszczenia zdjęciem z 2015 r., onet.pl, 4 IX 2020 [accessed: 21 III 2021], available online: <https://www.onet.pl/informacje/onetwiadomosci/awaria-czajki-tvp-ilustruje-zanieczyszczenia-zdjeciem-z-2015-r/oepsl3x,79cfc278>.

Dunai M., Hungary says to target tech giants over alleged manipulation of social media platforms, Reuters [online], 26 I 2021 [accessed: 18 IV 2021], available online: <https:// www.reuters.com/article/hungary-social-media-restrictions-idUSL8N2K13PY $>$.

Entman R. M., Framing: towards clarification of a fractured paradigm, “Journal of Communication" 1993, vol. 43(4).

Fazekas Z. et al., Elite-public interaction on twitter: EU issue expansion in the campaign, "European Journal of Political Research" 2021, vol. 60, issue 2.

Franczak K., Analiza ramowania, [in:] Analiza dyskursu publicznego. Przegląd metod $i$ perspektyw badawczych, eds M. Czyżewski, M. Otrocki, T. Piekot, J. Stachowiak,Wydawnictwo Akademickie Sedno, Warszawa 2017.

Gaub F. et al., Global trends to 2030 challenges and choices for Europe, European Strategy and Policy Analysis System, Brussels 2019, available online: [accessed: 8 III 2021]: 〈https://ec.europa.eu/assets/epsc/pages/espas/index.html〉.

Gąbka A., List Trzaskowskiego do Brukseli. „Wbicie sztyletu w plecy polskiemu rządowi”, tvp.info [online], 7 XII 2020 [accessed: 13 VI 2021], available online: <https://www. tvp.info/51216592/prezydent-warszawy-rafal-trzaskowski-chce-zeby-samorzadyotrzymywaly-fundusze-ue-z-pominieciem-rzadu>.

Goffman E., Frame analysis. An essay on the organization of experience, Northeast University Press, Boston 1986. 
Inotai E., Budapest Mayor: I'm not challenging Orban yet, Balkan Insight, 11 VII 2020 [accessed: 5 IV 2021], available online: <https://balkaninsight.com/2020/o7/11/ budapest-mayor-im-not-challenging-orban-yet/ $\rangle$.

Inotai E., Governing, not winning, seen greater test for Hungary's united opposition, Balkan Insight, 24 III 2021 [accessed: 3 IV 2021], available online: <https://balkaninsight.com/2021/03/24/governing-not-winning-seen-greatertest-for-hungarys-united-opposition/ $>$.

Katastrofa ekologiczna w Warszawie, wiadomości.tvp.pl [online], 28 VIII 2020 [accessed: 21 III 2021], available online: <https://wiadomosci.tvp.pl/44133302/ katastrofa-ekologiczna-w-warszawie $>$.

Katz B., Nowak J., The new localism: How cities can thrive in the age of populism, Brookings Institution Press, Washington 2018.

Lánchíd-ügy: Karácsony a saját közǵyülési határozatuknak sem tett eleget, Magyar Nemzet [online], 12 VI 2020 [accessed: 6 VII 2021], available online: <https:// magyarnemzet.hu/belfold/lanchid-ugy-karacsony-a-sajat-hatarozatuknaksem-tett-eleget-8236251/>.

Lindgren S., Digital media \& society, Sage, London 2017.

Maćkiewicz J., Ramy interpretacyjne jako narzędzie badań medioznawczych, „Studia Medioznawcze" 2020, tom 21, nr 3 (82).

Magyar Nemzet: Karácsonyék lenyúlják a vendéglátósoknak megitélt bértámogatást, Hirtv [online], 2 III 2021 [accessed: 6 IV 2021], available online: <https://hirtv. hu/ahirtvhirei/magyar-nemzet-karacsonyek-lenyuljak-a-vendeglatosoknakmegitelt-bertamogatast-2517790>.

"Mamy dość hipokryzji Trzaskowskiego", wiadomosci.tvp.pl [online], 16 VI 2020 [accessed: 21 III 2020], available online: <https://wiadomosci.tvp.pl/48554443/ mamy-dosc-hipokryzji-trzaskowskiego $>$.

MTI-Hungary Today, Coronavirus - Orbán: Virus must not be allowed to paralyse Hungary again, Hungary Today [online], 11 IX 2020 [accessed: 5 IV 2021], available online: <https://hungarytoday.hu/coronavirus-orban-virusparalyse-hungary-border-measures/ $>$.

MTI, Megkezdte a fóváros kiárusitását Karácsony Gergely, Hirado.hu, 21 I 2021 [accessed: 6 IV 2021], available online: <https:/hirado.hu/belfold/belpolitika/ cikk/2021/o1/21/megkezdte-a-fovaros-kiarusitasat-karacsony-gergely\# $>$.

Presidential Election The Republic of Poland 2020, National Electoral Commission, 3 IX 2020 [accessed: 21 III 2021], available online: <https://prezydent20200628. pkw.gov.pl/prezydent20200628/en>.

Newberry C., 36 Twitter stats all marketers need to know in 2021, blog.hootsuite.com, 3 II 2021 [accessed: 28 III 2021], available online: <https://blog.hootsuite.com/ twitter-statistics/>.

Newberry C., 47 Facebook stats that matter to marketers in 2021, blog.hootsuite.com [online], 11 I 2021 [accessed: 28 III 2021], available online: <https://blog.hootsuite.com/facebook-statistics/>. 
Niklewicz K., Retaking the cities: A plan for the centre-right, Wilfred Martens Centre for European Studies, Brussels 2020, available online [accessed: 7 III 2021]: <https:// www.martenscentre.eu/wp-content/uploads/2020/11/CES_POLICY-BRIEF_ Retaking-cities-V3.pdf $>$.

Niklewicz K., Communicating reform through social media: opportunities and risks, "e-Politikon" 2017, nr XXI.

Oficjalne wyniki wyborów 2018 Warszawa. Trzaskowski zdobył 56,67 proc. Dla kogo Rada Miasta?, gazeta.pl [online], 24 X 2018 [accessed: 3 IV 2021], available online: <https://wiadomosci.gazeta.pl/wiadomosci/7,114884,24080096,oficjalnewyniki-wyborow-2018-warszawa-trzaskowski-zdobyl.html $>$.

Olender, A., "Prześcignęliśmy nawet rosyjska telewizję". Badacz mechanizmów propagandy ocenia „Wiadomości” TVP, natemat.pl, 9 VII 2020 [accessed: 21 III 2021], available online: <https://natemat.pl/314153,wiadomosci-tvp-w-czasie-kampanii-wyborczej-medioznawca-o-propagandzie\# $>$.

Ozsvath S., Hungary's Fidesz party seeks to conquer social media, DW [online], 6 II 2021 [accessed: 6 IV 2021], accessed online: <https://www.dw.com/en/ hungarys-fidesz-party-seeks-to-conquer-social-media/a-56479198 $>$.

Pact of Free Cities, The official website of the Municipality of Budapest, 16 XII 2019 [accessed: 3 IV 2021], available online: <https://budapest.hu/sites/english/ Lapok/2020/pact-of-free-cities.aspx>.

Pbi, Wyniki badania Mediapanel za marzec 2021, Polskie Badanie Internetu Gemius [online], 6 IV 2021 [accessed: 6 IV 2021], available online: < https://pbi.org.pl/ badanie-mediapanel/wyniki-badania-mediapanel-za-marzec-2021/ $\rangle$.

Pakt Wolnych Miast podpisany, Warszawa. Oficjalny portal miasta, 17 XII 2019 [accessed: 3 IV 2021], available online: <https://www.um.warszawa.pl/aktualnosci/ pakt-wolnych-miast-podpisany>.

Prezydent Trzaskowski bezradny wobec awarii, wiadomości.tvp.pl [online], 1 IX 2020 [accessed: 21 III 2021], available online: <https://wiadomosci.tvp.pl/49662024/ prezydent-warszawy-bezradny-wobec-awarii $>$.

Reese S. D., Prologue - framing public life: a bridging model for media research, [in:] Framing public life: perspectives on media and on our understanding of the social world, eds S. D. Reese, O. H. Gandy, A. E. Grant, Routledge, London 2001.

Scheufele D. A., Framing as a theory of media effects, "Journal of Communication", March 1999, vol. 49, issue 1.

Schudson M., The News Media as political Institutions, "Annual Review of Political Science" 2002, vol. 5 .

Sikorski A., Is the end near for Viktor Orbán?, Human Rights Foundation - hrf.org, 25 III 2021 [accessed: 27 III 2021], available online: <https://hrf.org/press_posts/ is-the-end-near-for-viktor-orban/ $>$.

Stawiany J., "Wiadomości” o Trzaskowskim źle albo wcale, press.pl, 19 VI 2020 [accessed: 21 III 2021], available online: <https://www.press.pl/ tresc/62151,_wiadomosci_-tvp-o-rafale-trzaskowskim-tylko-negatywnie $>$. 
Sunstein C. R., \#republic, Princeton University Press, Princeton 2017.

Warszawa znów zatruwa Wisłę i Battyk, wiadomości.tvp.pl [online], 23 XII 2020 [accessed: 21 III 2021], available online: <https://wiadomosci.tvp.pl/51472270/ warszawa-znow-zatruwa-wisle-i-baltyk $>$.

Wody Polskie o „Czajce”: największa katastrofa ekologiczna na świecie, rdc.pl, 16 IX 2020 [accessed: 21 III 2021], available online: <https://www.rdc.pl/informacje/wodypolskie-zrzut-sciekow-do-wisly-najwieksza-katastrofa-ekologiczna-oczyszczalni-sciekow-na-swiecie/>.

V4C mayors' letter to Chancellor Merkel on direct, green, urban funding in the EU's next Multiannual Financial Framework, The official website of the Municipality of Budapest, 16 VII 2020 [accessed: 3 IV 2021], available online: <https://budapest. $\mathrm{hu} /$ sites/english/Lapok/2020/v4c-mayors-letter-to-chancellor-merkel-on-directgreen-urban-funding-in-the-eus-next-multiannual-financial-framework.aspx $>$.

Vass A., Coronavirus: Budapest Mayor denies PM Orbán's claims about capital's 100 billion plus, Hungary Today, 14 IX 2020 [accessed: 5 IV 2021], available online: <https://hungarytoday.hu/coronavirus-budapest-mayor-karacsony-100billion-government/ $>$.

Zalan E., Central Europe Mayors join in direct EU funds plea, "EUobserver" [online], 13 II 2020 [accessed: 11 III 2021], available online: <https://euobserver.com/ political/147435>.

Zielonka J., Is the EU doomed?, Polity Press, Cambridge 2014.

Zgut E., Orbán wants to further restrict the independent media. Hungary is a warning to Poland, Rule of Law, 23 II 2021 [accessed: 28 III 2021], available online: <https:// ruleoflaw.pl/orban-wants-to-restrict-independent-media-hungary-poland/>.

\section{Social media content}

Karácsony G., Facebook post, 29 X 2019 [accessed: 13 IV 2021], available online: <https://www.facebook.com/karacsonygergely/posts/2780097705356391〉.

Karácsony G., Facebook post, 16 XII 2019 [accessed: 13 IV 2021], available online: 〈https://www.facebook.com/karacsonygergely/posts/2892454184120742〉.

Karácsony G., Facebook post, 16 XII 2019 [accessed: 13 IV 2021], available online: <https://www.facebook.com/karacsonygergely/posts/2891946984171462〉.

Karácsony G., Facebook post, 12 II 2020 [accessed: 13 IV 2021], available online: 〈https://facebook.com/karacsonygergely/posts/3021840051182154〉.

Karácsony G., Facebook post, 17 VI 2020 [accessed: 13 IV 2021], available online: <https://www.facebook.com/karacsonygergely/posts/3331051866927636>.

Karácsony G., Facebook post, 15 VII 2020 [accessed: 13 IV 2021], available online: <https://www.facebook.com/karacsonygergely/posts/3409169925782496〉.

Karácsony G., Facebook post, 7 XII 2020 [accessed: 13 IV 2021], available online: <https://www.facebook.com/karacsonygergely/posts/3846629422036542〉.

Karácsony G., Facebook post, 9 XII 2020 [accessed: 13 IV 2021], available online: <https://www.facebook.com/karacsonygergely/posts/3851679331531551〉. 
Karácsony G., Facebook post, 11 XII 2020 [accessed: 13 IV 2021], available online: 〈https://www.facebook.com/karacsonygergely/posts/3857175414315276>.

Karácsony G., Twitter post, 7 IX 2020 [accessed: 13 IV 2021], available online: <https://twitter.com/bpkaracsonyg/status/1302979150626656258>.

Karácsony G., Twitter post, 8 XII 2020 [accessed: 13 IV 2021], available online: 〈https://twitter.com/bpkaracsonyg/status/1336203604139667461〉.

Karácsony G., Twitter post, 11 XII 2020 [accessed: 13 IV 2021], available online: 〈https://twitter.com/bpkaracsonyg/status/1337444795481001985〉.

Trzaskowski R., Facebook post, 10 X 2019 [accessed: 15 VI 2021], available online: <https://www.facebook.com/rafal.trzaskowski/posts/10157382647236091〉.

Trzaskowski R. Facebook post, 15 XII 2019 [accessed: 15 IV 2021], available online: <https://www.facebook.com/rafal.trzaskowski/posts/10157549139521091〉.

Trzaskowski R., Facebook post, 16 XII 2019 [accessed: 15 IV 2021], available online: <https://www.facebook.com/rafal.trzaskowski/posts/10157551031996091〉.

Trzaskowski R., Facebook post, 17 VII 2020 [accessed: 17 IV 2021], available online: <https://www.facebook.com/rafal.trzaskowski/posts/10158170066381091〉.

Trzaskowski R., Facebook post, 13 XI 2020 [accessed: 17 VI 2021], available online: <https://www.facebook.com/rafal.trzaskowski/posts/10158427890686091〉.

Trzaskowski R., Facebook post, 8 X 2020 [accessed: 17 IV 2021], available online: 〈https://www.facebook.com/rafal.trzaskowski/posts/10158353631196091〉.

Trzaskowski R., Facebook post, 7 XII 2020 [accessed: 17 IV 2021], available online: <https://www.facebook.com/rafal.trzaskowski/posts/10158477549786091〉.

Trzaskowski R., Facebook post, 7 XII 2020 [accessed: 17 IV 2021], available online: <https://www.facebook.com/rafal.trzaskowski/posts/10158478141496091>.

Trzaskowski R., Facebook post, 9 XII 2020 [accessed: 17 IV 2021], available online: <https://www.facebook.com/rafal.trzaskowski/posts/10158481169071091〉.

Trzaskowski R., Twitter post, 26 VI 2019 [accessed: 15 IV 2021], available online: 〈https://twitter.com/trzaskowski_/status/1143526592548941824〉.

Trzaskowski R., Twitter post, 25 VI 2019 [accessed: 15 IV 2021], available online: <https://twitter.com/trzaskowski_/status/1143467337716293632〉.

Trzaskowski R., Twitter post, 16 XII 2019 [accessed: 25 IV 2021], available online: 〈https://twitter.com/trzaskowski_/status/1206557987462139904〉.

Trzaskowski R., Twitter post, 12 II 2020 [accessed: 15 IV 2021], available online: 〈https://twitter.com/trzaskowski_/status/1227591095137243137〉.

Trzaskowski R., Twitter post, 12 II 2020 [accessed: 15 IV 2021], available online: 〈https://twitter.com/trzaskowski_/status/1227648560688181248>.

Trzaskowski R., Twitter post, 12 II 2020 [accessed: 17 IV 2021], available online: 〈https://twitter.com/trzaskowski_/status/1227648574646870016〉.

Trzaskowski R., Twitter post, 9 XII 2020 [accessed: 17 IV 2021], available online: <https://twitter.com/trzaskowski_/status/1336725120593833991〉. 